\title{
Ensuring Tenant Consultation Before Public Housing Is Demolished or Sold
}

\author{
Marvin Krislov
}

More than four million Americans live in federally funded public housing. ${ }^{1}$ Hundreds of thousands of others are waiting for apartments. ${ }^{2}$ These low-income families face an ever-growing shortage of affordable housing ${ }^{3}$ due to insufficient construction of public housing, ${ }^{4}$ demolition $^{5}$ and sale $^{6}$ of existing units, and tight supply in the private sector. ${ }^{7}$ When families can-

1. Matulef, This Is Public Housing, $44 \mathrm{~J}$. Housing 175, 176 (1987). This Note focuses on tenants living in conventional public housing. Under the Housing Act of 1937 ("the Act"), the federal government helps fund the construction and operation of housing projects to benefit low-income families. 42 U.S.C. \$ 1437 (1982 \& Supp. IV 1986). For recent amendments to the Act, see Housing and Community Development Act of 1987, Pub. L. No. 100-242, tit. I, 42 U.S.C.A. $\S 1437$ (West Supp. 1988) [hereinafter 1988 amendments].

The Housing Act was aimed at "assist[ing] the several States and their political subdivisions to remedy the unsafe and unsanitary housing conditions and the acute shortage of decent, safe, and sanitary dwellings for families of lower income." 42 U.S.C. § 1437 (1982). For the history of public housing, see, e.g., Bratt, Public Housing: The Controversy and Contribution, in Critical PerspecTives on Housing 335, 336-42 (R. Bratt, C. Hartman \& A. Meyerson eds. 1986) (hereinafter Critical Perspectives]. This Note discusses section 8 , which authorizes the federal government to pay up to $30 \%$ of an eligible family's rent to a private landlord, as well as other federally subsidized housing programs only insofar as these programs relate to public housing issues. For the provisions dealing with $\S 8$, see 42 U.S.C.A. $\S 1437 f$ (West 1978 \& Supp. 1988).

2. Matulef, supra note 1 , at $178-79$ (nearly 800,000 families on waiting lists with average wait of 13 months).

3. The shortage of low-rent housing is predicted to reach 7.8 million units by the year 2003 , causing as many as 18.7 million people to become overcrowded, homeless, or burdened by onerous rental payments. P. Clay, At Risk of Loss: The ENDANGERED Future of Low-InCOME ReNTAL Housing Resources 24 (1987).

4. See, e.g., Current Topic, Homelessness: Halting the Race to the Bottom, 3 YALE L. \& PoL'y REv. 551, 552 \& n.7 (1985) (decreased construction and loss of public and low-income housing units have been major cause of homelessness).

5. See, e.g., Herbers, Outlook for Sheltering the Poor Growing Even Bleaker, N.Y. Times, Mar. 8, 1987, at E5, col. 1 (more public housing units being destroyed than built).

6. Id.; see also President's Commission on Privatization, Privatization: Toward More EFFEctive Government 17-22 (1988) (federal government should promote both sale of public housing projects to tenants and private parties and terminate subsidies for public housing maintenance or debt service). But see Pear, Reagan Panel Urging Sale of Public Housing, N.Y. Times, Nov. 11, 1987 , at A20, col. 1 (housing officials assert recommendations would deprive low-income persons of aid).

This Note does not address the merits of selling public housing to tenants. The 1988 amendments established that the Act's tenant consultation requirements apply to sales of public housing to tenants. Compare 42 U.S.C. $\$ 1437$ (d) (Supp. III 1985) with 42 U.S.C.A. $\S 1437$ p(d) (West Supp. 1988) (climinating previous section exempting homeownership opportunities for lower income families from requirements including tenant consultation and relocation). Tenant associations may oppose the sale of apartments to residents, especially when it is seen as a strategy to cut aid and avoid rehabilitation. See Silver, McDonald \& Ortiz, Selling Public Housing: The Methods and Motivations, 42 J. HousING 213, 221 (1985).

7. See, e.g., W. Apgar \& H. Brown, The State of the Nation's Housing 1988, at 15, 19 
not locate an available apartment, they may be forced to move into substandard housing or become homeless. ${ }^{8}$

Local public housing authorities (PHAs), regulated by the United States Department of Housing and Urban Development (HUD), ${ }^{9}$ must respond to pressures from many sources. ${ }^{10}$ City officials and commercial interests may encourage PHAs to turn over property for private development. ${ }^{11}$ Local personnel may be frustrated by a real or perceived inability to manage a project. Reduced federal funding ${ }^{12}$ and statutorily limited rent receipts ${ }^{13}$ have strained the finances of numerous authorities. ${ }^{14}$ To cut operating expenses and avoid repairs, many PHAs have demolished or sold existing units. ${ }^{15}$

In 1983, Congress amended the Housing Act of 1937 to prohibit the Secretary of HUD from authorizing the demolition or sale of any public housing unless the PHA's application "has been developed in consultation with tenants and tenant councils, if any, who will be affected by the demolition or disposition."16 This "tenant consultation" requirement affords tenants the opportunity to participate in decisions affecting the fate of their project. Yet current regulations and practices fail to guarantee mean-

(1988) (only one in four households with incomes at or below poverty level lives in public or subsidized housing; growing rental burden, particularly among single-parent families, has contributed to rise in homelessness).

8. See, e.g., J. Kozol, Rachel and Her Ghildren: Homeless Families in America (1988); see also Comment, Homeless Families: Do They Have a Right to Integrity?, 35 UCLA L. REv. 159, 179-86 (1988) (describing difficulties of homeless families).

9. HUD delineates each PHA's rights and obligations in an Annual Contributions Contract. 42 U.S.C. $\S 1437$ (c) (1982 \& Supp. IV 1986).

10. Although the Housing Act states that PHAs should give some priority to families displaced by governmental action or emergencies, PHAs are not required to find either temporary or permanent housing for homeless persons. See 42 U.S.C. $\S 1437$ a(b)(3) (1982 \& Supp. IV 1986).

11. Property sales may help PHAs reduce deficits and operating expenses. Hartman, Housing Policies Under the Reagan Administration, in CRITICAl. PerSPectives, supra note 1, at 362, 367. Gentrification may encourage demolitions or intentional neglect. Id. at 366-68 (citing examples in Boston, San Francisco, and Alexandria, Va.).

Local support for abandonment may increase when a project is allowed to deteriorate. Id. at 367. Although local governments usually do not subsidize PHA operating expenses, they supply municipal services and may allocate funds for modernization. R. STRUYK, A NEW SySTEM FOR PUBLIC HousING: Salvaging a National Resource 77 (1980).

12. See, e.g., Hartman, supra note 11 , at 362, 365-66 (severe reductions in operating subsidies and modernization funds). PHAs rely heavily on federal funds for development and maintenance. In 1982, over half of all PHA operating expenses were paid by subsidies, primarily from the federal government; tenant rents comprised the rest of PHA income. In the large and very large PHAs, governmental subsidies represented an even greater share of operating expenses. R. DREWS, FEDERAL Subsidies for Public Housing: Issues and Options 33 (1983).

13. 42 U.S.C. $\$ 1437 \mathrm{a}(\mathrm{a})(1)$ (1982) (public housing rents limited to $30 \%$ of family's monthly adjusted income). Federal operating subsidies do not always make up the difference between the PHA costs per unit and rental receipts. R. DREws, supra note 12 , at 3.

14. A Dizzying Array of Public Housing Programs, 17 NAT'L J. 1797 (1985) (twenty-four financially troubled PHAs managed $20 \%$ of United States public housing in 1985).

15. See supra note 5 .

16. Pub. L. No. $98-181$, tit. II, $\S 214$ (a), 97 Stat. 1184 (codified at 42 U.S.C. $\S 1437 p(b)(1)$ (Supp. IV 1986)). Tenant organizations exist in most large and very large PHAs. Matulef, supra note 1 , at 181 . Even where there are no tenant organizations, the regulatory language indicates that tenants should be consulted. See 24 C.F.R. $\$ 970.4$ (1988) (application should be "developed in consultation with tenants of the project involved"). 
ingful tenant consultation ${ }^{17}$ before demolition or sale. Once a PHA decides to dispose of a property, it becomes difficult, if not impossible, to halt the process. The consultation process should enable tenants to suggest alternative uses for existing public housing units and to help plan for any displacement or relocation.

This Note argues that meaningful tenant consultation must occur before HUD approves the demolition or sale of public housing, and it proposes a framework for achieving that goal. Section I looks at recent judicial and congressional interpretations of the tenant consultation requirement, focusing on Edwards $v$. District of Columbia, ${ }^{18}$ the first and only case to discuss the consultation provision, and the subsequent legislative clarification of tenants' rights. ${ }^{19}$ Section II discusses the legislative history of the Act and the policy goals served by tenant consultation. Section III examines current problems in enforcing tenant consultation requirements. Finally, section IV offers a model mechanism for implementing the Act's tenant consultation provisions, consistent with congressional intent and policy objectives.

\section{The Edwards Decision and Congressional Reaction}

In 1977, the District of Columbia Housing Authority obtained federal funds to rehabilitate twenty-eight units in the Fort Dupont housing project. ${ }^{20}$ These funds were never spent. ${ }^{21}$ Instead, the PHA applied in 1981 for HUD's permission to demolish the apartments. Two years later, demolition was requested for an additional seventy-four units in the project. ${ }^{22}$

After more than a decade, HUD has not yet acted on the application to demolish Fort Dupont. Meanwhile, many tenants have been forced to move. ${ }^{23}$ Living conditions at Fort Dupont have deteriorated as apartments have remained vacant and unrepaired. ${ }^{24}$ According to the tenants, the PHA has quashed opposition to demolition by refusing to discuss its

17. "Meaningful tenant consultation" as used in this Note is defined as informed participation by tenants and tenant organizations in the consideration of demolition and sale proposals, thereby enabling tenants to voice their preferences, to offer alternatives, and to be involved in planning any displacement or relocation. This definition is based on the Act's legislative history and policy goals. See infra Section II; $g f$. Eisenberg, Participation, Responsiveness, and the Consultative Process: An Essay for Lon Fuller, 92 HARv. L. REv. 410, 415 (1978) (consultative process in general "involves assured participation that takes the form of affording affected parties the right to present reasoned argument and, to varying degrees, proofs for a decision in their favor").

18. 821 F.2d 651 (D.C. Cir. 1987), aff'g 628 F. Supp. 333 (D.D.C. 1985).

19. In the Housing and Community Development Act of 1987, Congress explicitly repudiated the Edwards decision. See infra text accompanying notes 35-37.

20. Edwards, 821 F.2d at 653.

21. Id.

22. Id. at 662 n.16.

23. Former Fort Dupont tenants claimed that housing officials forced them to move by threatening them with eviction if they resisted relocation. The reassigned tenants further claimed that their new housing was unsafe and unsanitary. Brief for Appellants at 12-13, 37, Edwards.

24. Edwards, 821 F.2d at 665, 666-67 \& n.1 (Will, J., dissenting) (citing affidavit of former city housing director). 
plans. ${ }^{25}$ In 1985, current and former residents of the Fort Dupont housing project sued the District of Columbia PHA, claiming that its officials had engaged in "constructive demolition"26 of their apartments without obtaining approval from $\mathrm{HUD}^{27}$ Gontending that the PHA had violated their consultation and relocation rights, ${ }^{28}$ tenants sought redress under section 1983. ${ }^{28}$

Writing for the court in Edwards, Chief Judge Patricia Wald concluded that section $1437 \mathrm{p}^{30}$ of the housing statute gives rise to a section 1983 action only after HUD has approved a demolition request. ${ }^{31}$ Relying on Pennhurst State School and Hospital v. Halderman, ${ }^{32}$ Judge Wald held that section 1437p does not impose "independent duties" on PHAs, but creates "conditions precedent" that must be satisfied before the Secretary of HUD may authorize demolitions or sales. ${ }^{33}$ According to Judge Wald, section 1437p does not use "sufficiently specific and definite" language to put a PHA on notice that it must consult tenants before asking for such authorization. ${ }^{34}$

\footnotetext{
25. Brief for Appellants at 11-13, Edwards.
}

26. "Constructive demolition" was defined as occurring when "a PHA intentionally seeks to circumvent the carefully crafted prerequisites of $\$ 1437 \mathrm{p}$ in order to pave the way for demolishing units in a federally funded housing project, regardless of whether the Secretary approves the demolition application or the units are actually (or about to be) demolished." Edwards, 821 F.2d at 658 (emphasis in original).

27. Brief for Appellants at 13, Edwards (noting that 150 of 300 units at Fort Dupont were vacant, despite waiting list of over 13,000 households for public housing in District of Columbia).

28. PHAs must relocate tenants displaced by demolition or disposition to "decent, safe, sanitary, and affordable housing, which is, to the maximum extent practicable, housing of their choice." 42 U.S.C. \$ $1437 \mathrm{p}(\mathrm{b})(2)$ (Supp. IV 1986).

29. 42 U.S.C. $\$ 1983$ (1982) is used as a vehicle for redressing civil rights violations by government actors. Plaintiffs in Edwards also alleged violations of procedural due process guarantees, a third party beneficiary breach of contract by HUD and the PHA, an "abuse of discretion" by HUD under the Administrative Procedure Act, and infringements of other provisions of the Housing Act. See 821 F.2d at 653.

30. 42 U.S.C. $\$ 1437$ governs the approval of demolitions or sales of public housing units. Before HUD may approve a PHA application, local government officials must state that the action does not conflict with local housing plans. 42 U.S.C. $\$ 1437 p(b)(1)$ (Supp. IV 1986). Local officials will not necessarily protect interests of public housing tenants. See infra notes 62-66 and accompanying text.

Sale or transfer of an existing property must be justified on one of three grounds: 1) protecting tenants' health and safety; 2) enabling the PHA to develop another project; or 3) "other factors which the Secretary determines are consistent with the best interests of the tenants and public housing agency." 42 U.S.C. $\$ 1437 \mathrm{p}(\mathrm{a})(2)$ (Supp. IV 1986). Similarly restrictive criteria govern HUD approval of a demolition request. Under the 1988 amendments, HUD may approve an application for demolition only where the project cannot be used or rehabilitated. 42 U.S.C. $\$ 1437$ p(a)(1) (Supp. IV 1986). Tenant consultation may enlighten HUD's evaluation of the usefulness and potential rehabilitation of a project. See infra notes 50-58 and accompanying text.

31. 821 F.2d at $659-60$ \& nn.11-12.

32. 451 U.S. 1, 18-19 (1981) ("bill of rights" provision of Disabled Assistance Act creates precatory goals rather than obligations enforceable in $\$ 1983$ actions).

33. 821 F.2d at 659 .

34. Id. at 657-58. Judge Wald asserted that Congress would need to rewrite the statute if it wanted to require PHAs to consult tenants in the process of "seeking" demolition approval. Id. at 658-59 (emphasis in original). Fort Dupont plaintiffs would have prevailed in a $\$ 1983$ action under the following hypothetical statute: "A PHA shall not seek to demolish a public housing project or units thereof except by consulting with tenants and providing for their decent, safe, sanitary, and affordable relocation." Id. at 658 . Judge Wald's hypothetical statute bears a strong resemblance to the 
Soon after the Edwards decision, Congress amended the Act to correct the D.C. Circuit's "erroneous interpretation of the existing statute."35 The new law provided that "[a] public housing agency shall not take any action to demolish or dispose of a public housing project or a portion of a public housing project without obtaining the approval of the Secretary and satisfying [the tenant consultation and relocation requirements]. ${ }^{336}$ Thus, the 1988 amendments established that $E d w a r d s$-type plaintiffs have a right of action under section 1983 to challenge "constructive demolition.".37

\section{The Value of Tenant Consultation}

Nonetheless, the present system does not guarantee meaningful tenant consultation because the scope of such rights remains uncertain. Creating detailed standards for section $1437 \mathrm{p}(\mathrm{b})(1)$ would fulfill congressional intent and would serve important policy goals.

\section{A. Congressional Intent: The Legislative History}

HUD regulations first required tenant consultation in $1979 .{ }^{38}$ Congress enacted a tenant consultation provision in 1983 which mandated that

law passed by Congress in 1988. See infra text accompanying note 36.

35. H.R. Conf. Rep. No. 426, 100th Cong., 1st Sess. 172, reprinted in 1988 U.S. Code Cong. \& AdMin. NEws 3458, 3469 [hereinafter Conference REPORT]. The Conference Report should be considered definitive, since later budgetary amendments did not affect the legislation relating to demolitions and Edwards. For the history of the 1988 amendments, see The 100th Congress: A Productive First Session, 45 Cong. Q. WeEkLY ReP. 3213, 3225 (1987).

36. 42 U.S.C.A. $\$ 1437 p$ (d) (West Supp. 1988). Proposed regulations implementing the new law do not specify the extent or nature of a PHA's obligation to eschew constructive demolition activities. See 53 Fed. Reg. 30,988 (1988) (proposed regulation to be codified at 24 C.F.R. $\S 970.12$ ).

Additionally, the 1988 amendments require that a PHA seeking approval for demolition or sale "developl] a plan for the provision of an additional decent, safe, sanitary, and affordable dwelling unit" for each existing unit that will be removed. 42 U.S.C.A. $§ 1437 \mathrm{p}(\mathrm{b})(3)$ (West Supp. 1988). PHAs may achieve this result through a variety of methods including project assistance, development of units assisted by state and local government, and tenant-based assistance. $I d . \S 1437 \mathrm{p}(\mathrm{b})(3)(\mathrm{A})$; see also 53 Fed. Reg. 30,988-89 (1988) (proposed regulations for "Replacement Housing Plan" to be codified at 24 C.F.R. § 970.11). But see infra note 73 (difficulties of guaranteeing effectuation of replacement housing plans).

37. In Wright v. City of Roanoke Redev. \& Hous. Auth., 107 S. Ct. 766 (1987), the Court found that federally created statutory rights could be enforced under $\S 1983$ unless Congress had foreclosed such action in the enactment or the statute failed to provide enforceable rights within the meaning of $\S 1983$. Id. at 770-71. The 1988 amendments clarify that neither of these exceptions applies to 42 U.S.C. \$1437p. See supra notes 35-36 and accompanying text.

The 1988 amendments may also give Edwards-type plaintiffs an implied private cause of action to enforce § 1437p. See, e.g., Cort v. Ash, 422 U.S. 66, 78 (1975) (four-prong test to determine whether federal statute implies private cause of action includes: whether plaintiff was part of intended beneficiary class legislative intent, consistency with legislative purpose, and relation of federal and state law remedies). The 1988 amendments, when read with the Conference Report, show that Congress viewed public housing tenants and applicants for such housing as beneficiaries of the statute. See supra notes $35-36$ and accompanying text.

38. 24 C.F.R. $\$ 870.7$ (1980); see also 24 C.F.R. $\$ 870.6(b)(5)$ (1980) ("views of tenants and the local governing body" among secondary criteria to be considered by HUD). The 1979 regulations required a notice and comment period for tenants and tenant organizations before a PHA could submit demolition applications to HUD. 24 C.F.R. \$ 870.7(a) (1980). The regulations called for PHAs 
PHAs consider tenant views before applying for HUD's permission to demolish or sell a project. ${ }^{38}$ The legislative history of the provision demonstrates that Congress intended to tighten the statutory requirements for demolition and disposition and to limit the discretion of PHAs. ${ }^{40}$ Moreover, both houses of Congress encouraged preservation of existing public housing stock and discouraged demolition. ${ }^{41}$

HUD promulgated new regulations in 1985 to enforce the tenant consultation requirement. ${ }^{42}$ These regulations did little to clarify the meaning

to "give full and serious consideration to the comments submitted by the tenants," to send HUD copies of all written comments and suggestions made by tenants and tenant organizations, and to notify tenants and the tenant organization when an application was submitted and when HUD rendered a decision. 24 C.F.R. $\$ 870.7$ (a)-(c) (1980).

39. Prior to the 1983 amendments, the Housing Act did not require tenant consultation. The Act stated a preference for rehabilitating existing units and required the PHA and HUD to agree that the project was "obsolete" or "unusable" before demolition would be approved. 42 U.S.C. $\S 1437 d(f)$ (1982) (repealed by 42 U.S.C. \$ 1437p (Supp. IV 1986)).

40. The floor manager of the legislation in the House, Banking Committee Chairman St. Germain, stated on the floor that: "This bill is intended to set standards limiting the circumstances under which public housing can be demolished or otherwise disposed. It is our intention that the standards in this bill be fully enforceable by tenants, tenants councils and through certification by local government officials." Subcomm. ON Housing and Community Dev. OF House Comm. ON Banking, Housing and Urban Affairs, 98th Cong., 2d Sess., Compilation of the Domestic Housing and International Recovery and Stability ACT of 1983 (Comm. Print 1984) [hereinafter Legislative HistoRy] at 319 (statement of Chairman St. Germain on House floor Nov. 18, 1983); see also S. REP. No. 142, 98th Cong., 1st Sess. 38, reprinted in id. at 895, 937 ("[T]he Secretary may approve an application under this section only if families to be affected, and local government officials, have been consulted.").

There is little legislative history discussing the tenant consultation provision, since the 1983 amendments were attached to a supplemental authorizations bill in a package that included domestic housing legislation and support for the International Monetary Fund. See Biggest 'Deal' Cleared in 1984 Supplemental, 39 Cong. Q. Almanac 536 (1984); Compromise Reached on Housing Revisions, 39 Cong. Q. Almanac 277 (1984). In a provision not incorporated into the Act, the House bill contemplated a more stringent form of tenant consultation-majority consent-that would have allowed the PHA to avoid two requirements for approval of demolition or disposition: 1) that a project be "substantially unoccupied," and 2) that the cost of rehabilitation exceed the cost of replacement. H.R. 1, 98th Cong., 2d Sess., tit. II, $\$ 213$ (1983), reprinted in Legislative HistorY, supra, at 562. This language might have encouraged tenant participation but would have minimized HUD's monitoring function.

41. See Legislative History, supra note 40 , at 319 (statement of Chairman St. Germain on House floor on Nov. 18, 1983) ("[I]t must be emphasized that the demolition or sale of any public housing project in this country should only be permitted as a last resort."); S. REP. No. 142, 98th Cong., 1st Sess. 38, reprinted in id. at 895, 937 ("[T]he Committee believes that every effort should be made to retain the present stock of public housing."); H.R. REP. No. 123, 98th Cong., 1st Sess. 36, reprinted in id. at 731, 766 ("The purpose of this provision is to ensure that the public housing stock remains available for housing low income families.").

Both the court opinion and the dissent in Edwards found that $\S 1437 \mathrm{p}$ had been enacted in the context of legislation that discouraged demolition of public housing. Edwards, 821 F.2d at 659 (Wald, J.); id. at 669-70 (Will, J., dissenting).

42. 24 C.F.R. $\$ 970$ (1988). HUD asserted that the new regulations would supply "additional language on standards and procedures only to the extent found to be essential to assure understanding of the legislative intent [of the 1983 amendments]." 50 Fed. Reg. 50,891 (1985) (final rule). The 1985 regulations omitted the statement in the 1979 regulations that HUD's policy was "to conserve and maintain the existing stock of low-income public housing to the maximum extent consistent with consideration of need and feasibility." See 24 C.F.R. $\$ 870.4$ (1980). HUD asserted that the 1985 regulations did not promote reduction of the public housing stock but "reflect[ed] a recognition by the Congress that there may be situations where disposition and demolition can be justified, and that PHAs should have reasonable flexibility." 50 Fed. Reg. 50,891 (1985). 
of appropriate tenant consultation ${ }^{48}$ and may have weakened existing rules. ${ }^{44}$ Although more specific than the 1985 regulations, HUD's 1986 Handbook fails to supply detailed standards for tenant consultation. ${ }^{45}$ Thus, the existing regulatory framework allows great latitude in both the extent of the PHA's tenant consultation and HUD's evaluation of that process. $^{46}$

\section{B. Purpose and Goals of Tenant Consultation}

Federal ${ }^{47}$ and state ${ }^{48}$ tenant consultation requirements reflect the ideological and pragmatic value of involving tenants in public housing decisionmaking. First, consulting tenants before demolition or disposition advances democratic and due process objectives. ${ }^{49}$ In addition, ensuring that

43. The 1985 regulations essentially repeated the statutory language: "HUD will not approve an application for demolition or disposition unless: The application has been developed in consultation with tenants of the project involved, any tenant organizations for the project, and any PHA-wide tenant organizations that will be affected by the demolition or disposition . . . 24 C.F.R. $\S 970.4(a)$ (1988). The new regulations required the PHA to include in its application "a description of the PHA's consultations with tenants and any tenant organizations . . . with copies of any written comments which may have been submitted to the PHA and the PHA's evaluation of those comments." 24 C.F.R. § 970.8(e) (1988). HUD's published comments did not define in more detail the appropriate form of tenant consultation. See 50 Fed. Reg. 50,892 (1985).

44. Compare, e.g., 24 C.F.R. $\S 870.7$ (1980) with 24 C.F.R. $\S 970.4$ (1988). The 1979 regulations require that the PHA "give full and serious consideration to the comments submitted by the tenants," 24 C.F.R. $\$ 870.7$ (a) (1980), while the 1985 regulations deleted any such requirement. The 1979 regulations require notice and comment before and after a request for demolition has been filed, and notice after a request has been acted upon; the 1985 regulations demand only a description of the consultation and copies of written comments that have been received.

45. The Handbook echoes the broad language of the regulations, promoting a "reasonable opportunity to present [tenants"] views" and "full and serious consideration to the comments and alternatives suggested by tenants and the tenant organization." U.S. DeP'T OF Hous. \& URBan Dev., Public Housing Demolition, Disposition and Conversion Handboor $§ 2-1$ (1986) [hereinafter HUD HANDBOOK]. The HUD Handbook describes the tenant consultation process in vague terms: The PHA must respond to the tenants "with a brief written evaluation of tenant recommendations ... . consistent with HUD requirements and the PHA's own determination of efficiency, economy, and need." Id. All written comments are forwarded to the HUD Field Office, which must evaluate the PHA response and recommend a course of action to the Regional Office. Id. In addition, the PHA must notify tenants in contiguous units when vacant units are proposed for demolition. Id. $\S$ $2-2$.

46. The regulations may be intentionally vague in recognition of the variety of ways PHAs can solicit input. Minimal guidelines do not preclude additional methods of tenant consultation.

47. Federal regulations require tenant consultation in a variety of contexts. See, e.g., 24 C.F.R. $\S 968.7$ (1988) (PHA application for modernization funds); $i d . \S 942.25$ (1988) (rules regarding pets in housing projects for elderly and handicapped).

48. For example, Massachusetts state regulations on tenant participation require a housing authority to recognize a city-wide tenant organization as well as any project-wide tenant organizations that request recognition. MASs. ReGS. CoDE tit. 760, $\S 6.02(3)$ (1986) (mandating recognition of tenant organizations). Moreover, the Massachusetts regulations detail procedures for resolving recognition disputes. Id. § 6.02(3)(d), (e) (local resolution); id. § 6.02(4) (appeal to state agency).

49. Although citizens have no federal constitutional right to public housing, Lindsey v. Normet, 405 U.S. 56, 74 (1972), decisions regarding its elimination should be governed by participatory and fairness norms. According to Professor Jerry Mashaw's "dignitary theory of due process," citizens should be treated as self-respecting moral and political agents; participation in administrative processes is thus fundamental to a liberal constitutional culture. J. MASHAW, DUE Process IN THE Administrative State 170-71, 270-71 (1985); see also Rubin, Due Process and the Administrative State, 72 CalIF. L. REv. 1044, 1150 (1984) (consultative process is alternative to civil trial model of procedural fairness). Congress also found democratic principles persuasive in requiring tenant con- 
public housing residents have a voice ${ }^{50}$ in planning is critical because these families have few or no alternatives to their current shelter. ${ }^{5 x}$ Tenants can best predict the impact of a proposed demolition or relocation, ${ }^{52}$ but they often lack a forum in which to articulate their views. ${ }^{53}$

PHAs also can benefit from tenant consultation. ${ }^{54}$ Whether or not tenants ultimately support a proposed demolition or disposition, their input can improve the quality of deliberations by the PHA and HUD. If desirable replacement housing is offered, residents may favor the demolition or sale of existing housing. ${ }^{55}$ They also can contribute to planning for replacement housing and relocation. ${ }^{58}$

Tenant consultation also can improve the use of existing public housing units. Residents may offer alternatives to a proposed demolition or sale or

sultation. See supra notes $40-41$ and accompanying text.

50. Fairness norms may require that those persons who have less economic ability to "exit" a market have greater "voice"- that is, participatory or voting rights - than those whose position allows them to leave with minimal costs. See A. Hirschman, Exit, Vorce and Loyalty 33-43, 120-26 (1970). In this regard, public housing tenants are analogous to workers governed by the National Labor Relations Act, 29 U.S.C. $\$ \S 157,158$ (d) (1982), who have a right to some measure of selfgovernance; by contrast, tenants are less like bondholders of a corporation, who generally can withdraw their investment at low cost.

51. Community opposition can prevent new public housing construction. See, e.g., James v. Valtierra, 402 U.S. 137, 143 (1971) (finding no racially discriminatory motive where construction of public housing blocked by failure of local referendum); United States v. Yonkers Bd. of Educ., $635 \mathrm{~F}$. Supp. 1577, 1580-81 (S.D.N.Y. 1986) (ordering city to develop 140 units of public housing as part of desegregation plan), affd, 837 F.2d 1181, 1193-94 (2d Cir.), cert. denied, 108 S. Ct. 2821 (1988). Anti-discrimination laws also restrict permissible sites for public housing development. See, e.g., 24 C.F.R. $§ 941.202$ (1988) (new public housing site normally must not be located in area of "minority concentration").

52. Possible consequences include homelessness and the psychological costs imposed by forced removal. See supra notes 2-8 and accompanying text.

53. See Atlas \& Dreier, The Tenants' Movement and American Politics, in CrrTical PERSPECTIVES, supra note 1, at 378, 390-91 (PHA tenant groups have not been well organized on federal level and have suffered from racial and class prejudice on local level); $(f$. Diver, The Optimal Precision of Administrative Rules, 93 YALE L.J. 65, 101 (1983) (public assistance beneficiaries and applicants "may lack the necessary knowledge, access, or incentive" to challenge existing eligibility standards or to demand explicit regulations).

54. See generally R. STRUYK, supra note 11, at 129-32 (both formal and informal tenant participation correlate with higher working performance by PHAs).

55. See, e.g., Homes Found for Tenants, New Haven Reg., Aug. 31, 1987, at 3, col. 6 (tenants support demolition and relocation plans); Newark Begins to Demolish Troubled Housing Projects, N.Y. Times, May 28, 1987, at B24, col. 1 (tenants praise city decision to demolish high-rises in favor of low-density public housing). Even prior to the 1988 amendments, challenges to proposed sales or demolitions were settled with agreements to supply replacement units. See, e.g., LaCorbiniere v. City of Providence, No. 81-0302B, slip op. (D.R.I. July 19, 1983) (consent decree ordered), cited in 17 Clearinghouse Rev. 1139 (1984) and in 16 Clearinghouse Rev. 455 (1982) (plaintiffs challenged sale of 256-unit project for upper-income condominiums on grounds including Fair Housing Act violations; settlement included rehabilitation for 112 units with priority given to low-income and minority persons); Colon v. Bethlehem Hous. Auth., No. 84-5219, slip op. (E.D. Pa. Nov. 7, 1985) (settlement agreement in which PHA agreed to apply for funding for 130 units to replace 500 demolished); see also Booker T. Washington Terrace Tenants Ass'n v. Pierce (U.S. Dep't of Hous. \& Urban Dev. filed Feb. 6, 1985), cited in 19 GLEARINGHouse Rev. 782 (1985) (\$3.8 million allocated to rehabilitate 140 of 300 units after plaintiffs complained of inadequate notice and opportunity to comment on proposed demolition, as provided under 1979 regulations).

56. Cf. Wilson, Planning and Politics: Citizen Participation in Urban Renewal, in URBAN RENEWAL: THE RECORD AND THE CONTROVERSY 407, 417-18 (J. Wilson ed. 1966) (urban renewal floundered partly because affected residents did not participate in planning for relocation). 
may assume management responsibilities. ${ }^{57}$ The involvement of concerned tenants and tenant organizations may help revive an ailing project. ${ }^{58}$

Ongoing communication between officials and residents reduces the likelihood of conflict. ${ }^{58}$ Meaningful tenant consultation increases the chance that the residents and the community will support the PHA decision. On the other hand, excluding tenants from the planning process may result in political opposition ${ }^{60}$ and protracted litigation. ${ }^{61}$

57. See, e.g., Fabri v. Rutherford Gounty, No. 80-3418, slip op. (M.D. Tenn. Feb. 11, 1983) (consent decree ordered) (minority plaintiffs purchased county-owned housing project after suing to stop demolition); Tenant Management of Public Housing: Hearing Before the Subcomm. on Housing and Community Dev. of the House Comm. on Banking, Finance and Urban Affairs, 99th Cong., 2d Sess. 13 (1986) [hereinafter Tenant Management Hearings] (testimony of Bertha Gilkey) (tenants took over project rather than see it demolished).

58. See, e.g., St. Hilaire, Public Housing Tenants' Anti-Displacement Strategy, 15 ClearingHOUSE REv. 250, 251-53 (1981) (public housing tenants helped leverage HUD modernization funds and worked to alleviate environmental hazards after housing project was saved from demolition); see also Comment, The Evolution of Conventional Public Housing in St. Louis, 5 PuB. L.F. 179, 193 (1986) (city-wide tenant organization helped plan relocation of tenants during rehabilitation).

59. See, e.g., McCray v. Beatty, 64 F.R.D. 107, 111-12, 115-17 (D.N.J. 1974) (settlement agreement approved where tenants had engaged in rent strike to protest imminent closing of project and unfavorable living conditions). Tenant-management conflict may impair working relationships even after specific dispute is settled. See, e.g., David, The Settlement of the Newark Public Housing Rent Strike: The Tenants Take Control, 10 Clearinghouse Rev. 103, 108-09 (1976) (bitterness and mistrust following settlement of rent strike).

60. See, e.g., Department of Housing \& Urban Development-Independent Agencies Appropriations Act, 1988, Pub. L. No. 202, tit. IV, $\S 415,1988$ U.S. CodE Cong. \& Admin. News (101 Stat. 1329) 123 (tenant opposition led to legislation forbidding expenditure of HUD appropriations to demolish Allen Parkway Village project in Houston and West Dallas housing projects); see also infra Section III (Allen Parkway Village) and infra note 61 (West Dallas).

61. For example, residents of a 2,600-unit project in West Dallas moved to intervene in a lawsuit in which the PHA and HUD had entered into a desegregation consent decree authorizing the demolition of public housing. See Walker v. United States Dep't of Hous. \& Urban Dev., No. 3-85-1210-R (N.D. Tex. Jan. 20,1987) (consent decree ordered), cited in Dallas Demolition Plan Will Replace 2,600 Units with Rent Subsidies, 14 Hous. \& Dev. Rep. (BNA) 505, 505-06 (1986). Plaintiffs, members of the certified class who were not named parties in the original suit, argued that they had not been adequately represented in the class settlement and contested the validity of HUD's approval of the consent decree on grounds including an alleged violation of the tenant consultation provision. The Fifth Circuit ruled, however, that plaintiffs' motion to intervene was untimely since it had been filed after the entry of the consent decree. Walker v. Mesquite, 858 F.2d 1071, 1074-75 (5th Cir. 1988). The Walker court did not reach the merits of plaintiffs' claims concerning tenant consultation requirements. Id. at $1074-75$.

Another Dallas lawsuit challenging the sale and demolition of a 347-unit public housing project lasted two years and aroused considerable controversy. See Wooten v. United States Dep't of Hous. \& Urban Dev., No. 3-82-2017 F, slip op. (N.D. Tex. Apr. 19, 1984) (settlement judgment entered where HUD agreed to provide funds for new construction and modernization); Public Housing Needs and Conditions in Dallas: Hearing Before the Subcomm. on Housing and Community Dev. of the House Comm. on Banking, Finance and Urban Affairs, 99th Cong., 1st Sess. 323-35 (1985) (hereinafter Dallas Hearings II] (analyzing demolition of Washington Place); see also Disposition of Public Housing-Dallas Housing Authority: Hearing Before the Subcomm. on Housing and Community Dev. of the Hoise Comm. on Banking, Finance and Urban Affairs, 98th Cong., 1st Sess. (1983) [hercinafter Dallas Hearings I] (Washington Place tenants' efforts to stop demolition). 


\section{Problems in Enforcing Existing Tenant Consultation REQUIREMENTS}

\section{A. The Discretionary Powers of Public Housing Authorities}

Although tenant consultation can benefit PHAs, ${ }^{62}$ public housing administrators have incentives not to seek tenant input before undertaking demolition. For example, PHAs may want to move quickly with a demolition or disposition and avoid questions or opposition.

Local housing officials exercise broad discretion in carrying out policies amounting to "constructive demolition." ${ }^{33}$ For example, PHAs may refuse to rent vacant apartments. ${ }^{64}$ Even after the 1988 amendments, such practices may evade scrutiny. ${ }^{65}$ Similarly, courts have declined to review living conditions and maintenance levels at housing projects. ${ }^{68}$

62. See supra Section II.

63. The original declaration of policy in the Housing Act of 1937 "vest[ed] in local public housing agencies the maximum amount of responsibility in the administration of their housing programs." 42 U.S.C. $\$ 1437$ (1982). As the courts have recognized, Congress subsequently has limited PHA discretion in certain areas. See, e.g., Wright v. Roanoke Redev. \& Hous. Auth., 107 S. Ct. 766, 774-75 (1987) (rent ceiling); Samuels v. District of Columbia, 770 F.2d 184, 200-01 (D.C. Cir. 1985) (Wald, J.) (mandatory administrative procedures for individual grievances). On the local level, however, public housing bureaucrats often can shape rules to suit their policy preferences. See, e.g., Samuels v. District of Columbia, 669 F. Supp. 1133, 1144-45 (D.D.C. 1987) (declaratory and injunctive relief ordered in light of PHA's "continuing efforts to block access to the grievance procedure"); J. Pynoos, Breaking the Rules: Bureaucracy and Reform in Public Housing 67-88, 194-200 (1986) (describing PHA discretion in selecting clients for public housing); R. STRUYK, supra note 11, at 110-18 (discussing PHA discretion in rental policies and income definitions).

64. No statute or regulation outlaws the practice of keeping units vacant. High vacancy rates have characterized many financially troubled PHAs, due partly to "questionable management practices to hold units vacant in anticipation of modernization." U.S. GEN. AccounTING OfFice, Public Housing Vacancies and the Related IMPact of HUD's Proposal to Reduce Operating SubsiDIES 6 (1985) [hereinafter VACANCIES REPORT]. Vacancy rates have tended to be higher in larger PHAs, where waiting lists also tend to be longer. Matulef, supra note 1 , at 180 .

PHAs receive funding from HUD based on the number of available units. Recent HUD regulations gradually reduce operating subsidies for PHAs with vacancy rates above three percent. 24 C.F.R. \& 990 (1988); 51 Fed. Reg. 16,835 (1986) (changes "encourage a PHA to maximize its total income by reducing its vacancies"). Some critics have charged that this reduced subsidy will encourage PHAs to undertake demolition or disposition, rather than shoulder the expense of rehabilitation. See VACANCIES REPORT, supra, at 13 (two of seven PHAs surveyed report that reduced operating subsidies would impair operations and might necessitate cutbacks). Although tenant consultation alone cannot solve the problem of high vacancy rates, tenant monitoring can check a PHA practice of leaving units unoccupied in order to make demolition more feasible.

65. The 1988 amendments do not specify whether excessive vacancies should be considered an impermissible "action to demolish." See supra text accompanying note 36 . In an analogous context, federal courts have construed the Housing Act to allow PHAs to keep units vacant, even where evidence suggested that those units were being held open illegally in anticipation of higher income tenants. See 42 U.S.C. $\S 1437 d(c)(4)(A)$ (Supp. IV 1986) (prohibiting "maintenance of vacancies to await higher income tenants where lower income tenants are available"); 24 C.F.R. $\$ 960.205$ (c)(8) (1988); see also Gholston v. Housing Auth., 818 F.2d 776, 787 (11th Cir. 1987) (high vacancy rate did not violate statute even where some evidence indicated housing authority had kept units vacant to await higher income applicants); Phelps v. Housing Auth., 742 F.2d 816, 820-22, 823 (4th Cir. 1984) (plaintiffs had no $\$ 1983$ rights to enforce statutory preference for lower-income families; equal protection not violated even if housing authority had kept apartments vacant for higher-income applicants). But see Martinez v. Rhode Island Hous. \& Mortgage Fin. Corp., 738 F.2d 21, 25 (1st Cir. 1984) (absolute preference for higher income applicants violates statutory policy of $\S 8$ program).

66. See, e.g., Edwards v. District of Columbia, 821 F.2d 651, 653-54 n.2 (D.C. Cir. 1987) (no federal rights to proper maintenance); Perry v. Housing Auth., 664 F.2d 1210, 1217-18 (4th Cir. 
PHAs may also attempt to remove tenants. Individual tenants can usually appeal evictions under a statutorily mandated grievance procedure, ${ }^{67}$ but even that avenue may be foreclosed if HUD has determined that the PHA's eviction procedures satisfy due process standards. ${ }^{68}$ Tenants cannot contest wholesale displacement or removal of residents through the grievance procedure, since that forum does not address class-wide complaints. ${ }^{69}$ Finally, PHAs exercise control over the amount and distribution of relocation assistance when a project is demolished or sold. ${ }^{70}$ To qualify for such assistance, tenants must receive an official PHA notice to move after HUD has approved a demolition or disposition request. ${ }^{71}$ As $E d w a r d s$ v. District of Columbia suggests, tenants may be intimidated into leaving a project without receiving official notice, thus forfeiting their claims to relocation assistance. ${ }^{72}$ Those displaced tenants may encounter difficulty in locating an available apartment, particularly if PHAs rely on section 8 certificates as replacement housing. ${ }^{\text {3 }}$

A compelling example of the way in which PHA discretion can work to chill tenant participation is the Houston Housing Authority's efforts to demolish Allen Parkway Village ("the Village"), the largest public housing complex in Houston. ${ }^{74}$ City officials and developers have wanted to use the land, prime downtown real estate, for commercial development and luxury condominiums. ${ }^{78}$ In 1979 , the Houston PHA received a $\$ 10$ million federal grant to modernize the complex, but spent less than

1981) (tenants lacked implied right of action and $\S 1983$ right to obtain relief for allegedly deficient housing).

67. 42 U.S.C. $\S 1437 d(k)$ (Supp. IV 1986). HUD regulations require that aggrieved tenants receive an informal grievance conference and, if no resolution is reached, a hearing before an impartial hearing officer. 24 C.F.R. $\$ \S 966.50-.57$ (1988); Samuels, 770 F.2d at 199-200 (tenants had $\S$ 1983 right to enforce requirement for grievance procedure).

68. 42 U.S.C. $\S 1437 \mathrm{~d}(\mathrm{k})$ (Supp. IV 1986).

69. 24 C.F.R. $\$ 966.51$ (b) (1988); see also Wright v. City of Roanoke Redev. \& Hous. Auth., 107 S. Ct. 766, 772 (1987) (PHA grievance procedures "open to individual grievances but not to class actions").

70. 24 C.F.R. $\S 970.5$ (1988); HUD HANDBOoK, supra note $45 \S 2-1$.

71. 24 C.F.R. $\$ 970.5$ (1988); HUD HANDBOOK, supra note $45, \S \S 2-2$ to -4 .

72. See supra note 23 and accompanying text.

73. See supra notes 1 and 36 . Uncertainties may mar the implementation of one-for-one replacement; tenants may have trouble locating an available $\S 8$ apartment; rehabilitation may fall behind schedule; housing may be driven out of the low-income housing market. See, e.g., CouncIL of LARGE Public Housing Authorities, Public Housing Today 8 (1986) (1982 HUD study of $\S 8$ certificate holders found that $72 \%$ of minority households and $52 \%$ of non-minority households could not locate an available unit). But see 42 U.S.C.A. § 1437p(b)(3)(B) (West Supp. 1988) (PHA must certify available private housing market if $\S 8$ certificates are to be used as replacement housing).

74. See Public Housing Needs and Conditions in Houston: Hearings Before the Subcomm. on Housing and Community Dev. of the House Comm. on Banking, Finance and Urban Affairs, 99th Cong., 1st Sess. 192 (1985) [hereinafter Houston Hearings]; U.S. Gen. Accounting OfFICE, PUBlic Housing: Proposed Sale of the allen Parkway Village Project in Houston, Texas (1986) [hereinafter Houston REPORT].

75. Flournoy, The Houston Project: City Works to Raze Public Housing, Dallas Morning News, June 9, 1985, reprinted in Houston Hearings, supra note 74, at 431, 435-37 [hereinafter Flournoy]. But see Letter from Earl Phillips, Executive Director of the Houston Housing Authority, to author (Nov. 16, 1987) [hereinafter Phillips Letter] (stating that no definite plan for new use of land has been made) (on file with author). 
$\$ 50,000$ on actual repairs. ${ }^{76}$ Housing officials then applied for permission to demolish Allen Parkway Village in $1984,{ }^{77}$ and in 1985 requested sale of the complex..$^{78}$ From 1977 to the present, the Houston PHA has evicted tenants, neglected routine maintenance and refused to rent vacant units. ${ }^{79}$ In December 1984, nearly half of the city's four thousand public housing residents lived in the Village. ${ }^{80} \mathrm{~A}$ recent survey found that only 130 families remain, ${ }^{81}$ although HUD has never approved any sale or demolition. ${ }^{82}$

Houston PHA officials also attempted to undermine tenant resistance to demolition. Administrators engaged in racial steering ${ }^{83}$ to alter the Village's composition and thereby weaken the black community's opposition to demolition. ${ }^{84}$ According to testimony, the PHA brought police to tenants' meetings and tried to invalidate an election for tenant organization

76. U.S. Gen. Accounting Office, Public Housing: Modernization of the Allen Parkway Village Housing Project in Houston, Texas 10 (1985).

77. Evidence suggests that the Houston PHA applied twice before 1984 to demolish the Village. According to one newspaper account, the Houston Housing Authority submitted a secret application to demolish the project in 1977, but was discouraged by Carter Administration housing officials. Flournoy, supra note 75, at 431-32. The article also found that the PHA subsequently applied to dispose of the Village in 1981, allegedly receiving endorsement from a top-ranking HUD official; the 1977 and 1981 applications were sent confidentially, without notifying tenants. Id. The Executive Director of the Houston Housing Authority has denied making applications for demolition prior to 1984. Phillips Letter, supra note 75. All accounts agree that the Houston PHA applied in 1984 for permission to demolish the Village. See id.; Flournoy, supra note 75, at 432.

78. The 1984 application for demolition stated that the PHA "anticipates a request for disposition." Phillips Letter, supra note 75; see also HousTON REPORT, supra note 74, at 6-7.

79. Houston Hearings, supra note 74, at 434; see also 1987 Developments in Federal Housing Law, 21 Clearinghouse Rev. 857, 861 (1988) [hereinafter Developments] (arguing Allen Parkway Village case presents facts "nearly identical" to those in Edwards).

80. HUD Fort Worth Regional Office \& Houston Office Staffs, Environmental assessment for the Demolition of Allen Parkway Village (1984) (opposing demolition because inadequate replacement units available), reprinted in Houston Hearings, supra note 74, at $209,264-65$. Nearly 13,500 Houston residents were waiting to be placed in public housing as of June 1985. Flournoy, supra note 75 , at 432 .

81. Once-Proud Project Faces Demolition: Razing Appears a Certainty for Low-Rent Housing, Houston Chronicle, Feb. 14, 1988, § 3, at 1; see also Allen Parkway Village Residents Council v. Housing Auth., No. H-87-564 (S.D. Tex. 1987) (arguing that PHA should be required to fill vacant units), cited in Developments, supra note 79 , at 861 n. 42 .

82. The request has been under consideration by HUD officials in Washington since August 1986. HousTON REPORT, supra note 74 , at 2.

83. Racial steering occurs when housing managers or landlords direct applicants of one race into one complex or area and away from another. In 1980, a federal investigation concluded that the Houston PHA was not complying with its approved tenant selection and assignment plan, thereby violating Title VI of the Civil Rights Act of 1964. U.S. DeP'T OF Hous. \& URBan DeV., Final Investigation Report: TItLe VI Complance Review of the Housing Authority of the CITY of Houston, Texas 1 (1981).

84. The black majority was replaced with a majority of Vietnamese and Cambodian refugees. Houston Housing Authority Accused of Racial Steering, N.Y. Times, Mar. 19, 1985, at A16, col. 1 (PHA report suggested that racial steering occurred because officials thought black and HispanicAmerican residents would protest Village demolition more effectively); see also Flournoy, Houston Project: Indochinese Makeup of Complex May Make Its Destruction Easier, Dallas Morning News, June 10, 1985 (many Asian newcomers given invalid leases subsequently evicted), reprinted in Houston Hearings, supra note 74, at 444-47; Houston Aide Accused of Ill-Treating Vietnamese, N.Y. Times, Mar. 20, 1985, at A22, col. 3 (PHA executive director accused of leveling racial slurs against Asian population). 
officers in which an anti-demolition slate had won. ${ }^{85}$ The tenant organization finally obtained a court-approved order wherein the housing authority agreed to refrain from further interference with elections. ${ }^{86}$

The tenant consultation that occurred was superficial. The Houston PHA never responded in writing to the tenant organization's alternative plan or to its critique of the demolition proposal. ${ }^{87}$ The speed of the PHA's decision ${ }^{\mathbf{8 8}}$ suggests that the views of the tenant council never were seriously considered. Although Houston officials had not polled residents, the officials told HUD that the majority supported demolition. ${ }^{89}$ Residents were not informed when the Houston PHA altered its application to request a sale of Village buildings, in addition to demolition. ${ }^{90} \mathrm{HUD}$ and a General Accounting Office (GAO) report nevertheless found that tenant consultation requirements had been satisfied. ${ }^{91}$

The Allen Parkway Village dispute is not unique. ${ }^{92}$ The lack of de-

85. Johnson v. Housing Auth., No. 84-2556, slip op. at 4 (5th Cir. June 26, 1985) (per curiam) (citing testimony before district court); Houston Hearings, supra note 74, at 193 (testimony of $\mathrm{L}$. Johnson).

86. Johnson v. Housing Auth., No. H-84-2682 (S.D. Tex. July 31, 1984) (agreed order issued based on First Amendment protection).

87. Houston REPORT, supra note 74, at 34-35.

88. The research team hired by the PHA conducted a public forum in June 1983. A communitybased coalition, including the tenant council, held a forum in August 1983, which resulted in a proposal favoring preservation of the Village. Nevertheless, the research team submitted a demolition plan in September 1983. The tenant council released its critique and alternative plan in November 1983. That same month the PHA voted to demolish all units. The tenant council was notified of the PHA decision in early December 1983. Id.

89. The tenant organization solicited comments through its own public forum in August 1983 and then sent HUD two hundred letters in opposition to the demolition and sale in March 1984. Id. In May 1984, the PHA responded to a HUD inquiry by denying that tenants had not been given adequate opportunity to comment and contending that the majority of residents favored demolition. Id. at 35 .

90. HUD interpreted the consultation requirements to include further consultation if a change would "materially affect" the tenants; the change from demolition to sale was not considered significant. Id. Federal officials therefore found that the Houston PHA had not been required to notify tenants of the March and October 1985 modifications to its application. Id. at 30. According to the agency, HUD has no written policy on allowing PHAs to amend applications, but permits changes when PHAs are responding to HUD inquiries. Id. at 31. Different standards govern demolition and disposition requests. See supra note 30 . Therefore, such a change affects those tenants who would contest the validity of a planned action.

91. HUD and the GAO evaluated the tenant consultation procedures under the 1985 regulations. The GAO report concluded that the act and its legislative history and HUD regulations do not "provide any guidance on how housing agencies are to consult and how the consultation requirement is satisfied." Houston REPORT, supra note 74, at 38 .

The GAO report noted that tenants had been allowed to present their views at Houston PHA Board of Commissioners meetings and on other occasions. Id. The Executive Director, Earl Phillips, has also pointed out that letters were mailed requesting written comments on the demolition proposal after the decision was made in December 1983 to proceed with the proposal. Phillips Letter, supra note 75.

Only one meeting was held with the PHA executive director, in May 1984, where tenants actually were informed about the demolition proposal. Houston REPORT, supra note 74, at 33 . No meetings regarding the later modifications were held.

92. Tenant organizations have tried unsuccessfully to discuss or modify pending demolition or disposition proposals. See, e.g., Dallas Hearings II, supra note 61; Dallas Hearings I, supra note 61; Cameron Valley Tenants May Sue, Alexandria Packet, July 1, 1987, at 15, col. 1 (PHA residents in Alexandria's largest housing project contemplated suit based on alleged violations of tenant consulta- 
tailed requirements for tenant consultation ${ }^{\text {} 3}$ allows PHAs to comply with the statute only nominally or when it has become too late for tenants to shape the decision.

\section{B. The Inadequacies of Litigation under the Present System}

Under current regulations, litigation may not ensure that tenants' views are taken into account. When a PHA fails to consult tenants or does so only nominally, tenants may turn to the federal courts to secure their statutory rights. Since the passage of the 1988 amendments, the federal courts must entertain such suits. However, neither existing regulations nor the 1988 amendments establish a test for determining when the tenant consultation provision has been violated. ${ }^{94}$ Edwards $v$. District of Columbia presented a rare case: there was no dispute over whether the tenants had been consulted. ${ }^{95}$ In analogous statutory contexts, the courts have been reluctant to monitor citizen participation requirements. ${ }^{98}$ Without evi-

tion requirements). Other tenant organizations are currently attempting to modify or prevent demolition plans. See, e.g., Concerned Tenants Ass'n of Father Panik Village v. Pierce, 685 F. Supp. 316, 320-21 (D. Conn. 1988) (holding 1988 amendments created rights enforceable under $\S 1983$ against de facto demolitions); Tillman v. Housing Auth. of Pittsburgh, No. 88-0311 (W.D. Pa. filed Feb. 17, 1988), cited in 22 Clearinghouse Rev. 173 (1988) (tenants challenge proposed demolition on grounds including alleged failure to consult with tenants); Project Residents Raise Protest, Detroit News, Aug. 25, 1987, at 3, col. 2 (tenants protest demolition decision).

93. The GAO has noted: "Neither the law, its legislative history, nor HUD's regulations prescribe specific types of consultation activities or how the consultation requirement is to be satisfied. . . [There is a] lack of written guidance on how a housing agency can satisfy the tenant consultation requirement." Houston REPORT, supra note 74, at 33. Even after the publication of the HUD Handbook, standards for tenant consultation remain vague. See supra note 45 and accompanying text.

94. The Edwards majority noted that plaintiffs' claims primarily involved "inaction . . . such as failure to consult with the tenants." Edwards v. District of Columbia, 821 F.2d 651, 662 n.16 (D.C. Cir. 1987). The PHA's motives were "difficult to ascertain." Id. at 662. Judge Will's dissent also seemed to find motivation significant: "[T]he plaintiffs, if permitted to proceed in district court, would face a difficult evidentiary burden. It is not easy to prove that a local government has engaged in a deliberate scheme to evade federal law. Nor is it easily proven that a federal agency abused its discretion." Id. at 671. The tenant consultation requirement, 42 U.S.C.A. $§ 1437 \mathrm{p}(\mathrm{b})(1)$ (West Supp. 1988), does not state that plaintiffs must prove a PHA's invidious intent, nor should such a standard be inferred from the legislative history. See supra Section II-A.

95. For the purpose of dismissal on summary judgment, plaintiffs' factual allegations were accepted as true by the Edwards court. 821 F.2d at 653. Given the 1988 amendments, PHAs can be expected to argue that tenants were adequately consulted before a request for demolition was submitted.

96. See, e.g., Drake v. Crouch, 377 F. Supp. 722,726 (M.D. Tenn. 1971), aff d, 471 F.2d 653 (6th Gir. 1972) (solicitation of majority of tenants door-to-door satisfied tenant participation requirements of HUD modernization program where no specific regulations had been issued). Where agencies have adopted specific requirements, courts have generally deferred to the agency action. See, e.g., Nickols v. Pierce, 556 F. Supp. 1280, 1292-97 (S.D. Ohio 1982) (citizen participation plan under Housing and Community Development Act satisfied where citizens invited to attend hearings and allowed opportunity to try to modify plan). But see Tenants \& Owners in Opposition to Redev. ("TOOR") v. United States Dep't of Hous. and Urban Dev., 406 F. Supp. 1024, 1039-40 (N.D. Cal. 1973) (redevelopment agency enjoined from demolition on grounds including failure to consult with leadership of minority groups and failure to report results of any consultation to HUD).

In an analogous context, the Government in the Sunshine Act, 5 U.S.C. § 552b (1982 \& Supp. IV 1986), has been difficult to enforce because its provisions require advance knowledge of a meeting. Even then, judicial review may not provide the desired result, since meetings may be canceled or 
dence of other violations by a $\mathrm{PHA}^{97}$ the courts are unlikely to review the record of tenant consultation under current law. ${ }^{98}$

Furthermore, federal lawsuits to enforce tenant consultation are timeconsuming and expensive. ${ }^{99}$ Any result less than a temporary restraining order may not help tenants seeking timely input. ${ }^{100}$ Even if a court blocks the disposal of a property, delays in participation will have harmed the tenants' ability to formulate alternatives and influence policy. ${ }^{101}$ Finally, court battles undermine an important value of consultation: cooperation between management and tenants. When these parties litigate, their divergent interests become entrenched and compromise becomes less likely. ${ }^{102}$

\section{A Model For Tenant Consultation}

More detailed requirements for tenant consultation should be adopted to ensure meaningful tenant participation. Congress, HUD, ${ }^{103}$ and local PHAs should institute this model framework to implement the statutory objectives. $^{104}$

decisions arrived at secretly. Furthermore, the absence of standards for relief may produce inconsistent judicial treatment. See J. Mashaw \& R. Merrill, Administrative Law: The American Public LAW SySTEM 53-54 (2d ed. 1985).

97. Such infringements might include racial discrimination or interference with free speech. See, e.g., supra notes 83-86 and accompanying text; $c f$. Hills v. Gautreaux, 425 U.S. 284, 305-06 (1976) (federal courts may order desegregation in public housing across city lines).

98. See Diver, supra note 53, at 108 ("courts' should be most sensitive to the plaint of . . . the adversarially disadvantaged public assistance recipient").

99. Litigation inflicts heavy financial costs and hurts the ability of both tenants and the PHA to plan for any changes. The prospect of displacement creates anxiety, particularly for the elderly and parents with young children, the two primary groups residing in public housing. See, e.g., O'Bannon v. Town Court Nursing Center, 447 U.S. 773, 784 n.16 (1980) (noting that elderly residents of nursing center may suffer "transfer trauma"-i.e., severe emotional and physical pain-as result of being moved).

100. Neither the statute nor the regulations require that a PHA delay a demolition or sale after HUD approval has been given. See 42 U.S.C.A. § 1437p (West Supp. 1988); 24 C.F.R. § 970 (1988); HUD HANDBOOK, supra note 45.

101. The Fort Dupont and the Allen Parkway Village examples show that litigation's slow pace allows PHAs to evict residents and discourage tenant consultation. Moreover, the most meaningful participation occurs in the formulation of options, not in protesting a previously made decision. See supra Section II-B.

102. But see Fiss, Against Settlement, 93 Yale L.J. 1073, 1085 (1984) (adjudication, rather than settlement, enables courts to interpret public values and secure justice for parties). The consultation provision does not guarantee tenants their desired outcome, but creates a participatory right. See supra note 17 and accompanying text.

103. See, e.g., Lefcoe, HUD's Authority to Mandate Tenants' Rights in Public Housing, 80 YALE L.J. 463, 480 (1971) (HUD "empowered to implement those specific . . . standards" when Congress directs tenant participation); Comment, HUD's Authority to Mandate Effective Management of Public Housing, $50 \mathrm{~J}$. URB. L. 79 (1972) (HUD should promulgate far-reaching rules to guarantee tenants' rights since PHAs face local constraining forces); $f$. Guardians Ass'n v. Civil Serv. Comm'n, 463 U.S. 582, 592 (1983) (agency may promulgate regulations which may be more stringent than terms of statute unless "clear[ly] inconsisten[t] with the face or structure of the statute, or with the unmistakable mandate of the legislative history").

104. This model proposes rules for tenant consultation, but does not preclude other forms of tenant involvement. This proposal draws upon ideas suggested in the U.S. DEP'T OF Hous. \& URBAN Dev., Final Report of the Task Force on Tenant Participation in the Management of LOW-INCOME Housing (1978) [hereinafter TASK FORCE REPORT], reprinted in Tenant Management Hearings, supra note 57, at 123; and other regulatory schemes, especially the Community De- 


\section{A. Proposed Tenant Consultation Regulations}

\section{Notice}

The PHA shall send written notice to all tenants and any tenant organizations in the project or those representing tenants city-wide at least six months prior to the submission of any application. ${ }^{105}$ Notice also shall be published in local newspapers and communicated through the broadcast media.

\section{Hearings}

At least sixty days ${ }^{108}$ before an application is submitted to HUD, the PHA shall convene a public hearing regarding the proposed demolition or disposition. ${ }^{107}$ The PHA and the project's tenant organization shall agree on the format. A HUD regional office staff member shall attend the hearing and prepare a written summary of the meeting. ${ }^{108} \mathrm{~A}$ tape recording and/or transcript shall be made and shall be included in the application. ${ }^{108}$

After the hearing, the PHA shall notify all tenants and tenant organizations if it decides to file a demolition or disposition request. A second hearing shall be held within thirty days of the submission to HUD, at which any changes to the original proposal shall be explained. ${ }^{110}$ Other hearings shall be held if HUD does not issue a final decision within a year of the second hearing.

velopment Block Grant program. The Task Force report addressed a broad spectrum of tenant participation issues and was adopted before the statutory tenant consultation requirement was passed in 1983.

105. The HUD Handbook provides for only "at least forty-five" days' notice. HUD HaNDBOOK, supra note $45, \S 2-1$. Such a short time does not allow tenants an opportunity to formulate alternatives. The proposed notice requirement would outlaw "secret" applications, give tenants "fair warning" and enable them to submit ideas at a meaningful point in the process. $C f$. TASK FORCE REPORT, supra note 104, at 18 (PHA should inform tenant organization at least one year in advance).

106. This notice gives both the PHA and the tenants sufficient time before the submission of any application. It also allows tenants time to study the situation before the PHA position has become entrenched.

107. Hearings and referenda are more effective ways to solicit tenant input than relying on written comments. See TASK ForCE REPORT, supra note 104, at 19 (public hearing should be held by PHA in local community before proposal submitted to HUD). The hearing should include families on the waiting list and the homeless and their advocates.

In an analogous context, the Community Development Block Grant program requires communities to hold one or more public hearings and provide opportunities for comment on any substantial changes. 42 U.S.C.A. § 5304(a)(2) (West 1978 \& Supp. 1988); of. 5 U.S.C. § 556 (1982) (formal rulemaking requires hearing).

108. The presence of a HUD staff member underlines the importance of tenant consultation and increases HUD administrators' understanding of local issues.

109. A permanent record allows HUD officials to evaluate the comments made at the hearing and prevents any misrepresentation of views. See supra note 89 and accompanying text; $c f$. 5 U.S.C. $\S 556$ (e) (1982) (requiring transcript and record for formal rulemaking).

110. This second hearing is especially significant if the PHA modifies its proposal, or if new facts have come to light. See supra note 90 and accompanying text. The proceedings should be transcribed or recorded and reported to HUD officials. 


\section{Referendum}

The PHA and the tenant organization shall agree on procedures and propositions for a tenant referendum. ${ }^{111}$ All adult residents of the project shall be allowed to cast a secret ballot. ${ }^{112}$ The results of the referendum shall be reported immediately to HUD and to tenants. If the majority of tenants voting oppose the plan, HUD may ask the PHA to negotiate further with the tenant organization and/or explain why tenants do not support the plan. ${ }^{113}$

\section{Negotiation and Mediation}

PHAs shall discuss proposals at all stages with the resident tenant organization and any city-wide tenant group. ${ }^{114}$ The resident tenant organization shall be asked to indicate its view, orally and in writing, before and after any application is submitted. ${ }^{115}$ The PHA and the resident tenant organization shall develop replacement housing and relocation assistance plans, if any are needed. HUD shall recommend and fund mediation activities when the parties would benefit from third party dispute resolution. ${ }^{116}$

111. The referendum ordinarily shall be held after the post-application hearing, but not more than sixty days after an application has been submitted unless there are unusual circumstances requiring an extension of time. HUD officials must not make any final decision until after the referendum is conducted.

112. Voting should be accessible to the elderly, the disabled, and those whose native language is not English. The referendum should be conducted in roughly the same manner as a public election, with polling for at least twelve hours and absentee ballots available.

This procedure would ameliorate disputes regarding the accuracy of the PHA's characterization of tenant views. See supra note 89 and accompanying text. A referendum will not bind the PHA or HUD. Under no circumstances should PHA or tenant organization officials be allowed to coerce or restrain tenants' votes.

113. Tenant opposition will not necessarily block a proposed sale or demolition. PHAs should explain to HUD why circumstances demand the veto of tenant desires. This step was not followed in Houston. See supra notes 87-91 and accompanying text. Even where tenant opposition is overridden, tenant consultation should inform PHA and HUD decisionmaking. See supra notes 54-61 and accompanying text.

114. This basic requirement was ignored in both the Fort Dupont and Allen Parkway Village examples. See supra notes 20-29 \& 74-91 and accompanying text. If the project does not have an organized tenant council, the PHA shall permit the election of a tenants' committee to represent tenants' views with regard to the proposed demolition or disposition.

115. The tenant organization cannot veto a proposal, however, since that would impinge on the PHA's administrative power and is not contemplated by the statute. See TASK FORCE REPORT, supra note 104, at 52 (Minority Report) (tenant organizations should not be required to concur in decision). But see id. at 18 (tenant organization must concur in application).

116. See, e.g., Phillips \& Piazza, The Role of Mediation in Public Interest Disputes, 34 HAsTINGS L.J. 1231, 1242-43 (1983) (mediation effective where government is defendant); see also TASK FORCE REPORT, supra note 104, at 22-23 (dispute settlement mechanism necessary for effective tenant participation). But see id. at 52 (Minority Report) (PHA Board cannot delegate decision). Mediation must receive the acceptance of the agreement by both parties, so PHAs would retain their authority. 


\section{B. Enforcing Tenant Consultation Requirements}

To make this framework effective, HUD must administer appropriate sanctions and rewards. ${ }^{117}$ This framework enhances the ability of courts to review consultation activities.

\section{HUD Monitoring}

HUD Field Offices shall supervise enforcement, with at least one staff member designated to oversee tenant consultation, to handle complaints, to receive reports on pending applications, and to issue regular reports to HUD Regional and Central Offices. ${ }^{118}$ If a complaint is filed regarding the tenant consultation process, HUD shall reply within fifteen working days, if practicable. ${ }^{119}$ Both the HUD Regional and Central Offices shall review the record of tenant consultation. ${ }^{120}$

\section{Sanctions and Bonuses}

HUD may impose sanctions on any PHA that fails to comply with these regulations. These sanctions may include withholding certain funds from the PHA and disciplining responsible personnel. ${ }^{121}$ Compliance with the regulations will result in the release of funds previously withheld; successful tenant consultation activities shall entitle a PHA to increased funding. ${ }^{122}$

\section{Judicial Review}

With this framework, litigants can obtain meaningful judicial review. If a PHA has violated the consultation requirement, federal courts should exercise their equitable powers and order the PHA to initiate consultation

117. These consultation procedures may be waived, with HUD's permission, for proposals involving fewer than ten units of public housing. This waiver provision recognizes that a proposal for demolition or disposition of a small number of units may not require elaborate tenant consultation, and therefore creates an appropriate triggering mechanism.

118. See TASK FORCE REPORT, supra note 104, at 23 (at least one staff person should monitor tenant participation and should be part of management review team). Confusion within HUD offices over distribution of authority may result in unclear policies. See generally HousTON REPORT, supra note 74.

119. This response requirement ensures that alleged violations of the tenant consultation process are investigated before it becomes too late for effective input. $C$ f. 42 U.S.C.A. $\S 5304(a)(3)(E)$ (West 1978 \& Supp. 1988) (requiring written answer within fifteen working days for complaints received regarding implementation of citizen participation in Community Development Block Grant allocation).

120. This creates a reviewable record for the benefit of HUD's Regional and Central Offices, as well as the courts. $C f$. 5 U.S.C. $\S 556$ (1982) (formal rulemaking requires record).

121. Monetary sanctions should be imposed only if they will not harm tenants' welfare and only when the PHA flouts HUD orders.

122. Such funding is currently available to tenant organizations under the modernization programs. Should a project be sold, the costs could be recouped from the proceeds of the sale. Sanctions and bonuses aim to alter the incentives for PHA's regarding tenant consultation. See supra notes 62-63 and accompanying text. 
activities immediately. Any steps toward demolition or disposition should be halted pending the conclusion of the consultation process. Those litigants challenging HUD's failure to enforce this framework must demonstrate that the agency abused its discretion. ${ }^{128}$ Should HUD approve a demolition or sale, plaintiffs then must demonstrate that the PHA violated the consultation guidelines. ${ }^{124}$

\section{Costs and Benefits}

The costs of implementing these regulations should be minimal. ${ }^{125}$ Tenant consultation saves money in the long run, ${ }^{126}$ since it can prevent costly mistakes, delays in property development, and litigation expense. ${ }^{\mathbf{2 7}}$

\section{ConCLusion}

Detailed regulations for tenant consultation will serve congressional intent and advance important policy goals. Any decision to eliminate housing significantly affects resident families' welfare and limits the lowincome housing supply in an area. Tenants contribute to the success or failure of any housing plan and deserve to be consulted.

For tenant consultation to be meaningful, both timing and procedures are critical. The 1988 amendments clarified that tenant consultation should occur before any constructive demolition begins. Plaintiffs now may call on the federal courts to enforce their consultation rights. To guarantee the integrity of the process, Congress or HUD should act immediately to define detailed standards for tenant consultation. Only

123. See, e.g., Heckler v. Chaney, 470 U.S. 821, 833-34 (1985) (agency decision not to initiate enforcement proceedings presumptively unreviewable under 5 U.S.G. $\$ 701$ (a)(2), but statute providing substantive guidelines can rebut this presumption); see also id. at 836 (leaving open possibility that "an agency's rules might under certain circumstances provide courts with adequate guidelines for informed judicial review of decisions not to enforce"). Furthermore, the Heckler Court did not rule out another claim that might be raised in the context of tenant consultation: that the "agency has 'consciously and expressly adopted a general policy' that is so extreme as to amount to an abdication of its statutory responsibilities." Id. at 833 n.4.

124. This model establishes a test against which courts can measure tenant consultation activities.

125. Providing notice, holding two hearings, running a referendum, and conducting negotiations are relatively inexpensive; the PHA cost will be primarily the time spent by its personnel. See Auerbach, HUD Should Raise the Roof with Overstaffed Authorities, Wall St. J., Dec. 17, 1986, at 32, col. 3 (East. ed.) (HUD official arguing that many PHAs have inflated staffs). HUD's expenses will not involve enormous additions of personnel time; in many instances, staff members have already been assigned to tenant consultation tasks. Mediators will not usually be employed and their fees should not be onerous.

126. See, e.g., Tobias, Of Public Funds and Public Participation: Resolving the Issue of Agency Authority to Reimburse Public Participants in Administrative Proceedings, 82 ColuM. L. REV. 906, 941, 955 (1982) (cost-effective benefits where public interest group participation, including attorneys' fees, funded by agencies). Tenant consultation will be much less expensive than formal public interest group intervention.

127. In some instances, the rehabilitation of existing stock can save PHAs and the various levels of government thousands of dollars, since new housing will not have to be constructed. Delays in development also raise costs for the PHAs. The expense of litigation far exceeds that associated with most administrative enforcement. 
through enforcement of such standards will tenants be ensured meaningful consultation. 